\title{
"Photomancias" ou a compreensão do mundo através da câmera-olho em $O$ fotógrafo, de Cristovão Tezza ${ }^{1}$
}

\author{
"Photomancias" or the understanding of the world through the eye camera in the novel \\ O fotógrafo, by Cristovão Tezza
}

Sheila Katiane Staudt

IFRS Campus Canoas. Canoas, RS, Brasil.

$\diamond$

\begin{abstract}
Resumo: O diálogo constante entre literatura e fotografia observado nas narrativas contemporâneas possibilitou identificar singularidades no modo de representação utilizado no romance $O$ fotógrafo, de Cristovão Tezza. Desde a nomeação dos capítulos - fotogramas - até a criação da ciência da 'photomancia', o texto se apresenta como uma coletânea de imagens fotográficas que se desdobram em infinitas possibilidades de intepretação acerca de aspectos recorrentes no universo urbano contemporâneo problematizados na ficção brasileira deste século. Compreender a cidade-labirinto - Curitiba -, bem como os sujeitos que fazem parte de sua composição é uma das preocupações do narradores-fotógrafos, leitores atentos àquele espaço plural em constante transformação.
\end{abstract}

Palavras-chave: literatura; fotografia; romance brasileiro contemporâneo.

\begin{abstract}
The constant dialogue between literature and photography in the contemporary narratives made it possible to identify singularities in the way of representation used in the novel O fotógrafo, by Cristovão Tezza. From the naming of the chapters - frames - until the creation of the science of 'photomancy', the text presents itself as a collection of photographic images that unfold in an infinite possibilities of interpretation on recurrent aspects in the contemporary urban universe problematized in the Brazilian fiction of this century. Understanding the citylabyrinth - Curitiba, as well as the subjects that are part of its composition is one of the concerns of the narrator-photographers, readers attentive to that plural space in constant transformation.
\end{abstract}

Keywords: literature; photography; contemporary Brazilian novel.

Publicado em 2004, O fotógrafo, do escritor Cristovão Tezza, foi reconhecido como melhor romance pela Academia Brasileira de Letras e melhor obra pela Revista Bravo!, além de conquistar o terceiro lugar do Prêmio Jabuti na categoria Romance e estar entre os finalistas do Prêmio Portugal Telecom de Literatura Brasileira.

Ambientada em Curitiba, cidade para onde o autor catarinense se mudou ainda criança, a narrativa tem como protagonista um fotógrafo nomeado uma única vez pelo seu segundo nome - Rodrigo - em toda a trama, e que só compreende o mundo por meio da lente de sua câmera fotográfica. Os capítulos, intitulados de 'fotogramas', encaminham o leitor a um verdadeiro álbum fotográfico, o qual contém recortes de um universo urbano complexo, impossível de ser compreendido no seu todo, mas passível de interpretação se capturado por partes. A técnica do chiaroscuro está presente e dialoga com os fotogramas, já que remete ao negativo de um rolo de filme fotográfico, originalmente em preto e branco. Nosso protagonista vive nas sombras, ao mesmo tempo em que é "mensageiro da identidade" (TEZZA, 2011, p. 13) alheia, ambiguidade que revela traços marcantes de seu caráter de homem moderno vivendo em um ambiente dividido, em que "tudo o que é sólido desmancha no ar" (MARX; ENGELS apud BERMAN, 1986).

\footnotetext{
1 Artigo elaborado a partir de um subcapítulo da tese de doutorado "Retratos urbanos em romances brasileiros do século XXI: uma leitura de Eles eram muitos cavalos, O fotógrafo e Satolep", defendida em 2015.
} 
O vocabulário escolhido pelo narrador advém do universo fotográfico, são verbos, substantivos, anglicismos e partes específicas do equipamento que se mesclam a todo instante às ações banais das personagens retratadas ao longo de um dia. Esse trabalho com a linguagem permite-nos vislumbrar outros fotógrafos, isto é, as demais personagens também utilizam o olhar para recortar o mundo à sua volta, a fim de compreenderem e discernirem tudo aquilo que se passa. O olho humano é, por assim dizer, a primeira máquina fotográfica, tendo servido de inspiração à criação das câmeras manuais, posto que estas possuem o mesmo mecanismo de inversão da imagem captada, primeiramente, pela íris.

Em um dos fotogramas em que o fotógrafo está em primeiro plano, ele relembra uma conversa com sua esposa Lídia, na qual intenta criar a ciência da "photomancia", pois, dessa maneira, ele seria capaz de entendê-la melhor: "fotografar a mulher era o lado visível de sua paixão; pelas fotos ele sabia como ela estava mais que isso, era como se desvendasse o futuro. Uma vez ele criou a ciência da photomancia. [...] Vou registrá-la; ficarei milionário" (TEZZA, 2011, p. 154). A partir desta deixa de nosso protagonista, tentaremos fazer uso desta "ciência", a fim de depreendermos os retratos coletados e expostos neste álbum singular, o qual identifica traços urbanos, humanos e experiências de relacionamentos esfacelados que se entrecruzam nesse período de um dia na cidade de Curitiba.

Para melhor entendermos o uso dessa prática, recorremos a estudos que aprofundassem a questão do "saber indiciário", método de conhecimento baseado, sobretudo, na observação. O pesquisador e historiador Carlo Ginzburg (1989, p. 153), em seu livro Mitos, emblemas e sinais, aborda o método indiciário e explica que "a arte divinatória [designa] coisas através de coisas". Sendo assim, além do protagonista - fotógrafo de profissão - e das demais personagens que registram tudo a seu redor, antevemos um outro fotógrafo: o narrador, o qual também utiliza a câmera e nomeia seus capítulos de "fotogramas". Portanto, os retratos exibidos nesse romance sinalizam o uso dessa ciência da "photomancia", uma vez que tentam desvelar tudo aquilo que, frente aos seus olhos, se apresenta. Ginzburg (1989, p. 98-99) constata ainda que

cada civilização situou a fonte do poder cósmico Deus - nos céus. [...] a advertência contra a pretensão de conhecer as coisas "altas" referia-se a níveis diversos de realidade, mas ligados entre si.

Mas, [...] o ressurgimento das palavras paulinas "noli altum sapere" em contextos diferentes reflete um pressuposto unitário implícito: a existência de um âmbito separado, cósmico, religioso e político, definível como "alto" e vedado ao conhecimento humano.
A busca pela verdade dos fatos é inerente à espécie humana. A curiosidade acerca de acontecimentos de difícil explicação científica parece atiçar o interesse pelo desconhecido. De acordo com o estudioso, por muito tempo, o acesso aos "altos saberes" foi proibido aos cidadãos pelos mais diversos campos do conhecimento: cósmico, religioso e político. Desse modo, qualquer "tentativa de ultrapassar os limites do intelecto humano" (GINZBURG, (1989, p. 97) era desencorajada pelos membros da Igreja e do Estado, com vistas a manterem a hierarquia social e política vigente. A utilização da expressão latina noli altum sapere fora do seu contexto original favoreceu a manutenção dos poderes e o afastamento de hereges e pensadores subversivos que ousassem burlar as regras preestabelecidas. De certa forma, a "photomancia" ciência divinatória pela qual uma personagem procura adivinhar a outra pela fotografia ou através de imagens retidas na memória pela câmera-olho - tenta alcançar uma espécie de "saber superior", na medida em que ele não está revelado, mas oculto, necessitando do meio fotográfico ou do resgate mnêmico para sair das sombras e vir à luz. As personagens buscam antever o futuro, bem como revisitar o passado fazendo uso dos recursos da "photomancia", em vez de consultarem Madame Susana, cartomante, cujos panfletos todas elas recebem e leem pelas ruas de Curitiba, talvez por entenderem ter aquela suporte mais científico e moderno que esta outra.

\section{1 "Photomancia" da cidade-labirinto}

\author{
"Não me aborrecia caminhar assim num mapa, \\ talvez porque sempre tive a vaga sensação de ser eu \\ também o mapa de uma pessoa." \\ (Chico Buarque, Budapeste)
}

A capital paranaense é o espaço no qual as ações acontecem no período total de um dia. Prédios, ruas, avenidas, praças, universidade, cinema são atravessados pelas personagens e dão pistas da velocidade moderna, que deixa mostras de um tempo líquido (BAUMAN, 2004), no qual todos estão simultaneamente imersos e submersos.

Fotografia e espelho, retrato e reflexo, imagem e representação, claro e escuro, luz e sombra são algumas dicotomias encontradas na narrativa. A utilização do objeto espelho e a presença de reflexos são recorrentes no texto. As personagens Íris, Lídia e o fotógrafo olhamse no espelho em algum momento daquele dia e analisam a imagem por ele refletida. Já Mara e Duarte avistam os reflexos de suas imagens no vidro de janelas: ela, de uma vitrine na rua; ele, de seu apartamento. Entender o 
romance como um jogo de espelhos ${ }^{1}$ é válido, uma vez que Umberto Eco afirma ser a fotografia um "espelho congelante" (ECO, 1989, p. 33) e, a partir disso, podemos estabelecer uma relação entre a sua metáfora e o abundante recurso fotográfico, ambos presentes na narrativa.

A reação da personagem Íris ao ver as fotos feitas pelo fotógrafo ratifica essa sentença: "- São as duas melhores fotografias da minha vida. [...] Esticou o braço mais uma vez, para se ver melhor naquele espelho" (TEZZA, 2011, p. 282). Conforme Gomes (2008, p.67), se "colocados frente a frente deformam a imagem e formam um labirinto - um ecoa no outro, ao infinito: 'bastam dois espelhos para construir um labirinto', declara Borges”. Sendo assim, a presença do labirinto está posta, tendo em vista que a fotografia tem papel essencial para a trama, tanto como objeto real quanto como signo-chave de interpretação, podendo ser entendida como outra forma de espelho, ao lado das diversas aparições deste objeto, propriamente dito, construtor basilar do labirinto.

Corroborando esse pensamento, Walter Benjamin (apud GOMES, 2008, p.69) acredita que "a cidade é a realização do antigo sonho humano do labirinto". Desse modo, percebemos que todas as personagens encontramse perdidas, seja no caminho real que trilham, seja em suas vidas privadas. A conexão entre elas, ao longo daquele dia, deixa pistas do "labirinto, "teia de filiações grupais' ou 'interseção de círculos sociais', que mostra os trabalhos da sociedade no nível das contínuas interações cotidianas" (SIMMEL apud GOMES, 2008, p. 74). A falta de um norte em suas vidas é o elo comum entre todas elas, por isso "o labirinto não é a trilha para chegar-se ao centro, é, antes, marca da dispersão. [...] O homem citadino é presa dessa cidade, está enredado em suas malhas" (GOMES, 2008, p. 68). A característica comum às personagens dessa narrativa tezziana vai ao encontro da propriedade dispersiva do labirinto, já que tanto elas, quanto o país como um todo vivem em uma época de transformação e mudança, ora tentando acertar o rumo da nação, ora buscando tomar as decisões mais sábias em suas escolhas pessoais e/ou profissionais.

Nesse sentido, Curitiba é o palco das ações registradas pelos narradores-fotógrafos e atua como labirinto, espaço singular, no qual recortes da cidade são a todo instante vislumbrados e ressignificados pelas personagens.

$\mathrm{O}$ entendimento sobre o local onde habita é necessário ao fotógrafo, pois, ao andar pelas ruas da cidade, ele tenta desvendar a história dos marcos citadinos e

\footnotetext{
1 Trabalhamos esse assunto no artigo "Jogo de espelhos: uma análise da construção narrativa de $O$ fotógrafo, de Cristovão Tezza", publicado no livro Literatura Brasileira Contemporânea: geografias, organizado por Gínia Maria Gomes, em 2013. Esse trabalho foi desenvolvido na disciplina do doutorado "Trajetórias da narrativa brasileira", ministrada por Antonio Marcos Vieira Sanseverino, em 2012/1.
}

hábitos urbanos. Já no fotograma que abre a narrativa, o protagonista analisa demoradamente o prédio indicado para o seu primeiro trabalho do dia:

[...] olhando para o alto - quantos andares? - [...] Oitavo andar, 803, Edifício Liberdade. Uma ironia, ele pensou, fantasiando a biografia do prédio: o dono da construtora, hoje com quase 60 anos, ouvia Jimi Hendrix e Janis Joplin e tropicália e era contra a ditadura militar. [...] Foi o orador da turma, imaginou. Nós erguemos o futuro, ele terá dito, pensando em prédios, e o fotógrafo sorriu. O primeiro prédio - este - recebeu o nome de Edifício Liberdade, em nome de nossos princípios. Talvez em 1972. [...] Serão mesmo vinte andares? Recomeçou a contá-los, de baixo para cima, mas um vulto saindo do hall desviou sua atenção (TEZZA, 2011, p. 7-8).

O crescimento vertical dos grandes centros urbanos não passa despercebido aos olhos do fotógrafo, que sinaliza para as construções típicas do universo contemporâneo: os enormes arranha-céus. Segundo Guy Petitdemange (apud PESAVENTO, 2002, p. 15), a arquitetura, por sua vez, expressa o "desejo coletivo inalcançável que se configura material e imediatamente". Por isso, ler a cidade física é ler sonhos e anseios dos que por ela passaram e deixaram suas marcas, como faz o fotógrafo ao tentar entender os ideais norteadores daquele grande edifício de vinte andares, projetado por aspirações coletivas de uma determinada época.

O não domínio do espaço é uma característica inata ao nosso protagonista: "as relações geográficas são estranhas, eu nunca dominei o espaço em três dimensões, sou um cretino topográfico" (TEZZA, 2011, p. 8). A convicção com a qual afirma não compreender a geografia que o circunda dialoga com sua personalidade sonhadora e sem os pés no chão, dificuldade que complica sua compreensão do lugar em que habita e impede-o de decifrar a linguagem dali proveniente, o que acentua ainda mais as características da cidade-labirinto, desnorteadora e voraz.

Após descer do edifício onde morava a moça Íris, ele reafirma seu total desconhecimento do território que o cerca e traça sua errância pelo labirinto citadino: "suado, pernas fracas, uma sensação agoniante de desconforto, o fotógrafo avançou três quadras sem rumo, até lembrar-se de que havia deixado o carro em outro lugar, na direção oposta - [...], e sentiu um desânimo duplo, [...]" (TEZZA, 2011, p. 39). Ao errar a direção em que havia estacionado seu carro, ele decide prosseguir e realizar o segundo trabalho do dia: "ir à Assembleia fotografar o filho da puta do deputado" (TEZZA, 2011, p. 39). Contudo, repensa sua situação e decide retornar, pegar o carro no local onde o havia deixado e acaba por desistir da ideia de encontrar o 
político. Aqui se evidencia ainda mais o homem indeciso, pois, como certifica Benjamin (apud GOMES, 2008, p. 68-69), "o labirinto é a pátria do hesitante. O caminho daquele que teme chegar ao fim, facilmente desenhará um labirinto". Ao adiar por algumas horas sua tarefa, a personagem mostra insegurança nas suas tomadas de decisão e perde-se em meio à cidade.

No turno da tarde, depois de deixar o carro para sua esposa e cruzar a urbe em um ônibus, com o intuito de finalizar a segunda tarefa daquele dia, nosso protagonista - tal qual um esgrimista baudelairiano ${ }^{2}$ - defende-se e esgueira-se da multidão:

Foi pedindo licença, cortando as filas compridas da espera dos ônibus, um cheiro de pipoca fresca no ar [...], desviou-se de uma senhora com um filho no colo que lhe estendia os dedos magros, uma exata simulação de sofrimento no rosto (não era uma boa fotografia, ele pensou) e desceu rápido os degraus que enfim o entregaram para a praça Santos Andrades, um espaço aberto, e ele respirou fundo, segurando firme a bolsa com o equipamento (TEZZA, 2011, p. 113).

A aglomeração humana e os obstáculos do percurso foram vencidos, pois segurava firme a bolsa com sua câmera ao longo da travessia, como um amuleto ou uma arma em prontidão. A destreza com que se desvia dos obstáculos à sua frente aproxima-o da figura do esgrimista criada por Charles Baudelaire, personagem habilidoso em andar em meio à multidão de acordo com a interpretação de Walter Benjamin (1985, p. 93). A mendicância - prática comum nas grandes cidades - é percebida e analisada pelo olhar do fotógrafo como não tendo as características de uma boa fotografia, posto que nota uma simulação de sofrimento esboçada no rosto da mulher que carregava o filho nos braços pedindo algum trocado.

Andando a pé, em busca do caminho mais curto para chegar ao local marcado, a diversidade de tipos humanos se apresenta frente a seus olhos:

Camelôs ofereciam óculos, cedês piratas, pilhas, brinquedos, relógios, ao lado de candidatos a camelôs (ele pensou) oferecendo volantes de propaganda de empréstimos bancários (DINHEIRO NA HORA!) e sortistas; ele espera o sinal verde da esquina agitada lendo o anúncio de Madame Susana [...] o mundo inteiro na rua neste fim de tarde, [...] (TEZZA, 2011, p. 117-118).

\footnotetext{
2 "Je vais m'exercer seul à ma fantasque escrime,/ Flairant dans tous les coins les hasards de la rime, / Trébuchant sur les mots comme sur les pavês /Heurtant parfois des vers depuis longtemps rêvés." Poema "Le soleil", Fleurs du Mal, de Charles Baudelaire.

"Ali sozinho, exercito a minha estranha esgrima,/Farejando por todo canto o acaso da rima, /Estrebuchando sobre palavras como sobre assoalhos/ E às vezes topando com veros há muito sonhados" (apud BENJAMIN, 1985, p. 93-94)
}

As artérias do ser chamado cidade estão cheias de vida em constante vibração, como percebe nosso protagonista. $\mathrm{O}$ "mundo inteiro" parecia estar ali naquele final de tarde: ambulantes, entregadores de propaganda, passantes, enfim, o cristal - racionalidade geométrica - e a chama - emaranhado de existências humanas (CALVINO, 1990) preenchem esse espaço plural que abriga a tudo e a todos. O mercado oferece-se aos clientes na forma de "camelôs", ou seja, trabalhadores com emprego informal que sobrevivem da venda de mercadorias, muitas vezes, falsificadas, porquanto mais acessíveis no que tange ao custo repassado aos fregueses. Essa modalidade encaixa-se na categoria dos subempregos cada vez mais crescente devido à saturação do mercado de trabalho e à grande concorrência às vagas ofertadas, como mostra o registro dos "candidatos a camelôs" disputando o espaço urbano.

A admiração pelo local em que habita fica evidente no retrato intitulado "O fotógrafo vai à cidade". O olhar arguto da personagem também recai sobre a cidadelabirinto, que o confunde a todo o momento:

Caminhou durante um bom tempo pelo alto das Mercês de onde, em alguns momentos, podia comtemplar quase que a cidade inteira, que parecia estranhamente silenciosa, um distante e escuro perfil de prédios contra um céu um pouco menos escuro [...] Como é bonito aqui, não? - Lídia lhe disse, segurando-lhe a mão, quando saíram para caminhar à noite muitos anos antes, ao comprar aquela mesma casa no que então parecia o fim do mundo, casa que hoje era uma velhice fora de lugar rodeada de cidade nova por todos os lados (TEZZA, 2011, p. 217).

O estranhamento no que diz respeito à falta de ruído na cidade, ao avistá-la de um lugar mais distante, perturba o fotógrafo, uma vez que o seu costume é presenciar a agitação e o burburinho constantes próprios de um grande centro urbano. Signos do passado e do presente convivendo pacificamente, ao mesmo tempo, são características da modernidade, visto que ela se define pela "presença do passado no presente" (STAROBINSKI apud AUGÉ, 1994, p. 71). Desse modo, a casa em que morava com a esposa e a filha, comprada em local remoto da cidade há anos, hoje não está em sintonia com a moderna arquitetura que a rodeia. A "cidade nova" cerca a "velhice" da casa, novo e velho, passado e presente coabitando esse espaço plural.

Ainda andando pela cidade e mergulhado em lembranças de cenas de sua vida passada, o fotógrafo é quase atropelado por um veículo em alta velocidade: "A lembrança das fotografias parece tê-lo acalmado - ele voltou a andar. [...] Vamos esquecer isso, ele disse em voz alta, e em seguida um carro passou a dois metros dele 
numa velocidade absurda, desaparecendo na curva - o fotógrafo pareceu acordar" (TEZZA, 2011, p. 219). De acordo com Sennett (2008), o novo ambiente moderno é caracterizado pela tríade velocidade, fuga e passividade, deste modo a coexistência de seres passivos (como o nosso protagonista), ao lado de carros velozes compõem o complexo painel urbano moderno, outra dicotomia própria da contemporaneidade. Apenas a rápida passagem do carro, muito perto de seu corpo, traz de volta a personagem à vida real.

Nesse mesmo fotograma, ele parece humanizar a cidade, mostrando alguma sintonia com o local em que habita:

Atravessou a rua e, um pouco adiante, parou para respirar - estava suando - e contemplou de novo a cidade, bela, imóvel e soturna diante dele. Em alguma janela próxima uma luz se apagou, e ele ficou um tempo procurando luzes que se acendiam e se apagavam e se surpreendeu com aquela vida subterrânea se movendo em toda parte, braços esticando-se para ligar e desligar lâmpadas: a cidade respira (TEZZA, 2011, p. 219-220).

A contemplação mais acurada do ambiente, à primeira vista inerte e soturno, permite ao fotógrafo sentir que não está só, mas ao lado de um ser que "respira". A presença de vida por todos os lados daquele labirinto urbano humaniza o corpo chamado cidade (SENNETT, 2008) e surpreende a personagem que observa aquele espetáculo singular em sua travessia a esmo pela geografia desconhecida de Curitiba.

No trajeto incerto que trilha, o fotógrafo se depara com sujeitos estranhos e um tanto suspeitos, o que o faz acenar para um táxi e sair de seu percurso como meio de fuga:

A proximidade de uns vultos no outro lado da rua, [...] assustou-o. Eram quatro ou cinco figuras, talvez adolescentes, fumando, e uma risada artificial chegou até ele, junto com um olhar. Ele apressou o passo, [...] Um dos adolescentes parece que atravessava a rua em direção a ele, e ele via somente o brilho do cigarro aceso que se movia em pêndulo. A luz providencial de um táxi salvou-o; fez um sinal e assim que o carro parou como que se jogou dentro dele, o coração disparado - pelo vidro traseiro, via a figura erguendo os braços, talvez desolada. (TEZZA, 2011, p. 223)

A insegurança nos grandes centros urbanos pode ser vista nesta passagem. A desconfiança ante o grupo gera um sentimento de autossalvação na personagem que, ao avistar um táxi, pula para dentro do veículo a fim de escapar do encontro com os rapazes na rua. No cotidiano das grandes cidades, o carro serve como meio de segregação social (SENNETT, 2008), sendo utilizado como espaço de proteção e conforto, em contraponto ao ambiente externo perigoso e sujeito a intempéries.

A esse respeito, Baudrillard (apud DELLE DONNE, 1990, p. 200) afirma que

toda a grande cidade é hoje a imagem do mundo inteiro, espaço homogeneizado sob o signo da coexistência pacífica e, ao mesmo tempo, da discriminação dos ghettos do terceiro mundo. A cidade, o urbano, é um espaço-tempo neutralizado, homogeneizado, um espaço-tempo de indiferença, e no conjunto um espaço-tempo do aprofundamento das diferenças, da segregação crescente dos ghettos urbanos, do desterro dos bairros, das raças, de certos grupos etários: o espaço despedaçado dos signos distintivos.

Através das palavras do estudioso, percebemos ser a cidade esse local ambivalente que propicia tanto o convívio harmônico entre as pessoas como também o acirramento das diferenças sociais, raciais, ideológicas, etc., unindo e afastando os que nela habitam. Não só Curitiba, mas qualquer cidade apresenta-se como esse locus da indiferença para com o outro, como mostra a atitude do fotógrafo ao querer distanciar-se do grupo de adolescentes que vinha em sentido contrário ao seu.

Ao descer do táxi, ele reafirma sua inaptidão para reconhecer o local em que se encontra:

Atravessou a rua, momentaneamente confuso com a geografia - mais alguns passos e se perguntou no escuro: Esta é a Comendador Macedo ou a Nilo Cairo? - até que três minutos depois se viu diante do Edifício Liberdade, e ele deu dois passos para trás, como quem chegou cedo demais ao seu destino [...] olhando em torno como quem custa reconhecer, afinal, que sim, é exatamente aqui que você queria chegar depois de todas essas voltas, [...] (TEZZA, 2011, p. 245)

Tal qual um autômato, o fotógrafo percorre o labirinto urbano sem saber claramente o seu destino. Contudo, o ponto de partida é o ponto de chegada para ele: o prédio de Íris, lugar em que começara e também terminara o dia. Após caminhar e olhar a cidade ao seu redor, o fotógrafo está à procura de sua Ariadne, como um verdadeiro homem labiríntico.

A analista Mara, por sua vez, anda pela cidade no final do dia e também fotografa, por meio da câmeraolho, cenas do cotidiano urbano que trazem signos antes nunca vistos:

Na marquise do Correio Velho passou por um estreito pátio dos milagres, cuja existência discreta só agora ela percebia, como quem se esforça para pensar em outra coisa: velhos de muletas, velhas com crianças no colo, vendedores de loteria, doces, esmolantes e molambentos, um breve espaço sujo entre os 
jornais das bancas, as paradas dos ônibus, as figuras sobreviventes, a sombra espessa de uma árvore arruinada, [...] (TEZZA, 2011, p. 150).

O narrador machadiano de Esaú e Jacó já asseverava nas primeiras linhas do romance: "nem todos podem dizer que conhecem uma cidade inteira" (MACHADO DE ASSIS, 2008, p. 1075). Idêntica constatação é feita por essa personagem ao fixar sua câmera-olho nos detalhes desta cidade-labirinto com o intuito de não pensar nos problemas da paciente Íris. O pátio dos milagres era-lhe antes totalmente desconhecido, talvez por estar em local de difícil acesso ou visibilidade estreita. A riqueza de detalhes descobertos nessa travessia desapressada pela urbe faz com que Mara vislumbre novas perspectivas do próprio lugar em que habita. A dificuldade em se conhecer toda uma cidade advém das constantes transformações por que passam os grandes centros urbanos ou mesmo da correria a que nos sujeitamos diariamente, bitolando, assim, nossos percursos e olhares. Em relação a esse espaço, impõe-se a referência do romance Notre Dame de Paris, de 1831. Nele, o escritor Victor Hugo nomeia um bairro parisiense de "Pátio dos Milagres": "cidade dos ladrões; asilo monstruoso onde o boêmio, o frade que abandonou o hábito, o estudante que abandonou as aulas, os birbantes de todas as nações [...]; de todas as religiões, judeus, [...], cobertos de chagas fingidas, mendigando de dia, transformando-se de noite em bandidos" (HUGO, s/d, p. 31). A semelhança entre os tipos humanos encontrados nos dois locais aponta marcas da segregação urbana e da formação dos ghettos nas grandes cidades, espaços isolados em que predominam a violência e o abandono, como mostram as duas narrativas.

Mais adiante, a analista se depara com uma diversidade de tipos destoantes no tempo e no espaço: "A poucos metros, alguns artesãos - meio hippies, meio ciganos, meio sujos, ela pensou, defendendo-se do racismo provável: são apenas morenos; são apenas sobreviventes - ofereciam badulaques de metal, dois homens, uma mulher, como que arrancados dos anos 70 para a boca do século XXI" (TEZZA, 2011, p. 151). A plural composição urbana parece-lhe tão estranha que o incomum na imagem daqueles vendedores ambulantes faz com que os mesmos sejam vistos como seres "fora de lugar", pertencentes a uma época remota. Para Sennett (2008, p. 360), "as pessoas não acolhem as diferenças, a dessemelhança cria hostilidade, a melhor expectativa está na tolerância". Desta forma, o diferente é visto como hostil aos olhos de Mara, que apenas aparenta tolerar a cena, pois classifica-os como sobreviventes naquela selva urbana.

De acordo com Willi Bolle (2000, p.400), as "grandes cidades [...] simbolizam riqueza e progresso, ao mesmo tempo em que se transformam em imensos formigueiros humanos, superpovoados, cada vez mais inchados: megalópoles, onde se acumulam o ouro e a sucata da humanidade", e tornam-se o local por excelência onde convivem seres dos mais variados tipos. A última cena urbana avistada por Mara lança luz a um problema comum das grandes cidades: a mendicância. Sentada em um banco de praça, a analista lembra-se das filhas, enquanto percebe as pessoas ao seu redor:

\begin{abstract}
Alguém parou pedindo esmola com uma ladainha cansada mas ansiosa, dinheiro para pegar um ônibus de volta para a cidade dele, a casinha em que viviam pegou fogo, e ela apertou a pequena bolsa sem olhar para o homem, levantando-se dali enquanto ele continuava mentindo; desviou o olhar de uma mulher que também se aproximava de mão estendida [...] (TEZZA, 2011, p. 152).
\end{abstract}

Sem olhar para o homem que contava a "falsa" história triste de sua vida a fim de conseguir alguns trocados, Mara levanta-se e sai de perto, segurando firme sua bolsa, contudo, outra mulher já se aproximava com a mesma intenção. Nos dois encontros, a analista desvia o olhar daquelas criaturas, dando mostras de indiferença prática esta comum entre as pessoas nas cidades.

Conforme o sociólogo Erving Goffmann (apud SENNETT, 2008, p. 368), "a desestimulação defensiva influencia as pessoas até mesmo nos locais por onde elas caminham, isto é, o modo como elas administram seus corpos nas ruas: ao olhar de relance segue-se um posicionamento que acarrete o menor risco de contato físico". A rapidez com que a analista levanta e foge daqueles pedintes vai ao encontro desta lógica de autodefesa praticada nos grandes centros urbanos, pois, como complementa Sennett (2008, p.368), “é possível reduzir-se a complexidade da experiência urbana afastando-se dos outros, mediante um conjunto de clichês, o cidadão sente-se mais à vontade; ele pressente a realidade e desloca o que lhe parece confuso ou ambíguo". Fugir do contato é a saída de Mara frente àquela situação de desconforto na qual se encontra ao ser abordada por pessoas pedindo dinheiro em uma praça da cidade.

Lídia e Duarte, ao contrário de Mara, dirigirem-se para o cinema na sessão da tarde e também se deparam com tipos comuns das grandes cidades: "E de repente, subindo quatro degraus entre dois mendigos que conversavam tranquilos ali sentados, um em cada ponta da escada breve, viu-se diante do Cine Luz" (TEZZA, 2011, p. 74). A diferença econômico-social é igualmente registrada pela câmera-olho dessas personagens. Após despedir-se de seu professor, Lídia vai em direção à escola da filha, mas no caminho se vê diante de outros tipos: “- Tenho de buscar Alice - ela disse em voz alta o suficiente para 
atrair o olhar curioso do catador de papéis que descansava ao lado de seu carro lotado de lixo sob a marquise do prédio azul" (TEZZA, 2011, p. 136). Mendigos, pedintes, vendedores, artesãos, catadores ganham o espaço das ruas que, muitas vezes, constitui seu próprio lar. Por outro lado, a fisionomia urbana revela-se, aos poucos, nesses retratos feitos nos mais diferentes trajetos citadinos.

Caminhando pela cidade, após a sessão de cinema, Duarte tenta entender o que se passou entre ele e sua aluna Lídia e apreende a escrita urbana por meio dos tipos singulares nela habitados:

Uma mulher passava rapidamente com um carrinho de bebê; crianças pobres subiam no canhão da Segunda Guerra, aos gritos; uma delas se aproximava dele para pedir esmola e ele se levantou imediatamente. Estava a três quadras de casa, ele calculou. Já estou perto.

- Tem um dinheirinho aí, tio?

Fez que não, sem olhar para o menino, apressando o passo (TEZZA, 2011, p. 103).

A indiferença para com o outro é característica do individualismo moderno. O professor responde negativamente ao pedido do menino e sequer olha para ele, fato este que está em consonância com a desigualdade econômico-social presente nos grandes centros urbanos. Conforme as pesquisas de Sennett (2008, p.358), “a multiplicidade não incita as pessoas a interagir". É o que acontece com Duarte ao apressar seu passo e nem ao menos olhar para o garoto que lhe pede "um dinheirinho". Mais adiante, em seu percurso, o professor avista outro pedinte, agora um tanto quanto bizarro:

parado na esquina da Benjamin Constant, os olhos acompanhando o andar ostensivo, de certa forma militar, da perna mecânica, nua, engrenagens à mostra - clact-clact! - de um mendigo avançando para ele como o soldado sobrevivente de uma guerra, a mão exigente estendida, um refugiado da Bósnia, ele pensou, reprimindo o riso estúpido daquela perna absurda pedindo esmola como uma instalação da Bienal, e desceu a rua cheia de árvores, sem responder, [...]. (TEZZA, 2011, p. 105)

A mendicância nas ruas da cidade é percebida pela câmera-olho do professor, que registra os detalhes do estranho pedinte, com a perna mecânica à mostra, o qual confiava na compaixão humana para receber alguns trocados. A interação interpessoal não é favorecida pela variada composição humana de que são feitas as metrópoles modernas, como afirmou o estudioso Sennett (2008), pois, nas duas situações, o "diferente" é ignorado pelo professor que acelera sua marcha rumo ao conforto do lar, da mesma forma que fez sua esposa anteriormente em situação similar.
Duarte capta ainda outras cenas que focalizam atores sociais pertencentes à categoria do "refugo humano" (BAUMAN, 2005):

descobriu na escuridão da rua um negro seminu puxando uma carroça de papéis, latas de alumínio, tubos plásticos, o lixo reciclável, uma carroça alta como a carroça de feno de Hieronymus Bosch (Jesus te Ama aos céus, sobre a miséria humana); e no alto do feno, a criança acomodada sobre um trono de papelão. Como um animal dócil e esforçado, o homem puxava aquilo contra a leva de carros que, já em boa parte civilizados, farejavam o obstáculo, tateavam o caminho, desviavam-se, às vezes com lentidão respeitosa, surpreendentemente sem buzinar, daquela peça infernal arrastando o lixo - um respeito, talvez, ponderava Duarte, $[\ldots]$ o primor negro que arrastava aqueles - duzentos? trezentos? - quilos sem olhar para os lados, os músculos de Apolo reluzentes na escuridão sob os fachos de luz; ao chegar à esquina, o homem aproveitou um lapso de espaço em branco para, numa corrida infinitesimal, chegar à proteção do outro lado, sem derrubar a carroça que balançou com a criança ao alto, e seguiu, soturna e sólida, rua acima. (TEZZA, 2011, p. 110-111)

A figura do chiffonnier ou trapeiro pode ser vislumbrada nesse retrato detalhado da cidade. "O apanhador de papéis ou catador de lixo, que recolhe tudo e nada ao mesmo tempo" (PESAVENTO, 2002, p.49) é fotografado pelo professor e revela mais um contraste urbano: a lentidão e precariedade das carroças, disputando espaço com os veículos velozes modernos - os carros. A animalização humana é vista nesta passagem, uma vez que não há cavalos para puxá-la, mas sim um homem negro, forte e ágil, comparado ao deus grego Apolo, ao realizar aquele trabalho sobre-humano pelas ruas, levando tudo e, a um só tempo, nada de muito valor. Diversos contrastes sobrepostos nessa fotografia são revelados: carro versus carroça; animal versus homem; homem versus máquina; e mostram a essência ambígua da urbe composta por antagonismos, pois, conforme Sandra Pesavento (2002, p. 225), esse fenômeno de coexistência e permanência do antigo e do novo, do passado e do presente faz parte do processo de modernização urbana tão comum nas grandes cidades.

O intertexto com a obra do pintor holandês Hieronymus Bosch (1450?-1516) intitulada "O carro de Feno"3, a qual tem formato tripartite e compõe o "Tríptico do Feno", não passa despercebido ao leitor, visto que a imagem remonta à mensagem do provérbio que diz: "O

\footnotetext{
3 O quadro original encontra-se no Museo del Prado, em Madri. Disponível em: <https://www.museodelprado.es/coleccion/galeria-on-line/galeriaon-line/zoom/1/obra/el-carro-de-heno/oimg/0/> Acesso em: $10 \mathrm{dez}$. 2014. (Vide ANEXO C)
} 
mundo é um monte de feno, cada qual tira o que pode". No romance, a quantidade de lixo rejeitada por outros homens será reaproveitada pelo negro que dali tirará o sustento da sua família. Cada um usufrui, usufruiu ou usufruirá de maneira diferente daqueles objetos feitos de alumínio, de papel, de plástico, etc., isto é, bens materiais desejados pelo homem em quantidades cada vez maiores com vistas a saciar, momentaneamente, seus prazeres e caprichos. O lixo, como o feno, é o objeto da cobiça humana no mundo moderno. Desprezado em meio à cidade por aqueles que já tiraram dele seu proveito, ele passa a ser fonte de renda ao negro, que o arrasta em meio aos perigos do caótico trânsito urbano como um tesouro.

Repleto de signos bíblicos típicos do imaginário medieval, o tríptico boschiniano retrata a cobiça e o individualismo como impregnados no cerne da natureza humana. A personagem Duarte classifica aquela visão como "infernal" tal qual a obra de Bosch, que tenta mostrar os vícios humanos e sua derrocada inevitável. No quadro, como que impossibilitado de intervir nas ações terrenas, Deus apenas observa a degradação humana. $\mathrm{Na}$ narrativa, a frase entre parênteses também mostra o distanciamento do Criador, que apenas observa dos céus toda aquela miséria.

Ao sentar alguns minutos para ponderar sobre o que havia de real na experiência arrebatadora vivida no cinema, ao lado de sua aluna, o professor atenta para os marcos urbanos referenciados mais pela força do hábito do que pela função histórica neles contida: "Decidiu sentar no banco da pracinha do avião - ou praça do Expedicionário, ele conferiu na plaquinha azul o nome oficial do espaço por onde passava todos os dias - como quem se prepara, toma fôlego mental, para chegar em casa" (TEZZA, 2011, p. 102). O nome real daquele lugar familiar era-lhe até então desconhecido. Duarte passa a saber a nomenclatura oficial ao lê-la na placa indicativa. Os estudos de Kevin Lynch (2006, p. 04) vão ao encontro desta procura do ser humano por espaços conhecidos: "a necessidade de reconhecer e padronizar nosso ambiente é tão crucial e tem raízes tão profundamente arraigadas no passado, que essa imagem é de enorme importância prática e emocional para o indivíduo". Identificar o que está à nossa volta faz com que a interação com o meio aconteça, propiciando os deslocamentos e o reconhecimento dos diversos pontos da urbe, a exemplo do que faz Duarte ao memorizar o nome do local por que passava diariamente.

Pelo vidro da janela de sua sala, Duarte revela querer ter o controle da cidade vigiando a todos através de binóculos potentes:

[...] os passos o foram levando para a janela. [...] vendo a cidade escura e aqui e ali uma janela ou outra se acendendo ou se apagando. Sempre desejou ter um binóculo potente - e uma perna quebrada como desculpa, e ele sorriu - para controlar a cidade inteira no painel desta janela, mas a ideia envergonhava-o tanto que jamais conseguiu sequer verbalizar o desejo. [...] Sentou-se e ficou imóvel contemplando a escuridão tranquila de Curitiba (TEZZA, 2011, p. 236).

O desejo nunca revelado pelo professor esconde a vontade de observar cada suspiro da sua cidade pelo recorte de sua janela. $\mathrm{O}$ acender e apagar das luzes na cidade escura encanta-o de tal forma que a pretensão de possuir binóculos para ter o domínio daquele espetáculo noturno torna-se um segredo guardado só para si mesmo. Sem poder concretizar seu anseio secreto, Duarte sentase e apenas contempla a escuridão serena de sua cidade. A intertextualidade com um dos clássicos de Alfred Hitchcock - Janela Indiscreta, de 1954 - faz-se presente nessa passagem e não poderia deixar de dialogar com a temática de cunho fotográfico que permeia a narrativa, já que o protagonista do filme também é um fotógrafo de profissão que, impedido de exercer seu ofício, por estar com uma perna quebrada, observa os vizinhos através de sua janela com o zoom de sua câmera. Em ambas as narrativas, há a mudança de foco das duas personagens, as quais, acostumadas à rua, estreitam sua visão com o enquadramento da janela e passam a "se deparar com outro tipo de espetáculo, o show da vida das pequenas criaturas que inundam o mundo das metrópoles" (KUSTER, 2009, p.12). Sobre esse redimensionamento do campo de observação, Francis Montcoffe (apud KUSTER, 2009, p. 12) afirma que no filme

O olhar que exercer-se-ia a partir de uma "front window" captaria apenas a vida turbulenta e, de uma certa forma, indefinida da rua e da cidade. Este perceberia as manifestações ritualizadas e teatralizadas da existência urbana, enquanto o olhar que parte da "rear window" assiste ao espetáculo de uma população liberada do jogo social, e que pode ser, enfim, ela mesma. [...] A "rear window" revela, por conseguinte, a verdade desses seres, enfim desembaraçados de toda hipocrisia social.

Penetrar o detalhe é o desejo das personagens tanto no filme quanto no romance. O narrador, que compila esta coletânea de fotografias, utiliza uma espécie de telescópio para aproximar a história de cada uma das personagens e projetá-las nas páginas de seu álbum, retirando assim suas máscaras sociais.

Ser observado e observar o outro são práticas frequentes nos grandes centros, uma vez que controlar o outro ou o espaço que nos cerca tornou-se lugarcomum na contemporaneidade, haja vista a quantidade de câmeras de vigilância espalhadas pelas cidades, prometendo trazer a almejada segurança aos cidadãos 
em suas travessias. Acerca desse controle sobre o outro referido tanto no romance quanto no filme, Michel Foucault (1987, p. 225-226) nos lembra que "o panóptico é uma máquina maravilhosa que, a partir dos desejos mais diversos, fabrica efeitos homogêneos de poder". O panóptico referido por Foucault é um dispositivo de vigilância criado por Jeremy Bentham, com a finalidade de "domesticar" os corpos em diversos estabelecimentos de ordem (prisões, escolas, fábricas, dentre outras). A relação de poder existente nesse desejo inconsciente de observar o outro fica explícita, pois, ao conhecer os passos e hábitos alheios, conseguimos estar um passo à frente de suas intenções e, por conseguinte, exercer um domínio antes inexistente.

Ao contrário do fotógrafo, a capacidade de reconhecer e dominar o ambiente aparece na figura do traficante, que precisa reconhecer pessoas e locais a fim de exercer sua influência nociva. Após o happy hour, Íris volta para casa acompanhada de um amigo. Nesse instante, ela avista o traficante e descreve o seu domínio naquele pedaço da cidade:

$\mathrm{Na}$ esquina, ela viu, já sem surpresa, o pequeno traficante, como sempre, a controlar a sua geografia universal, o guardador de gentes com a medida do guardador de carros, território que começava na praça do Café Teatro e avançava quem sabe até a igreja de Guadalupe, oito ou nove quadras e algumas transversais escuras e pulsantes [...] (TEZZA, 2011, p. 211).

A imagem do guardador de gentes que procura suas vítimas para fornecer prazer imediato a um alto custo o do vício - está registrada nesse retrato, bem como a sua habilidade em situar-se em um pedaço de território definido e bem conhecido por ele. Ter o controle total do espaço e das gentes que por ali circulam faz-se necessário, tendo em vista que, por estar transgredindo a ordem preestabelecida, precisa saber onde ficam as rotas de fuga para qualquer eventualidade.

Nesses recortes feitos por diferentes olhares sobre a cidade, delineia-se a fisionomia da cidade-labirinto, a qual envolve e dispersa a todos por suas veias e artérias, provocando encontros e desencontros; contatos desejados e indesejados; infinitos cruzamentos com o emaranhado de existências humanas que compõe aquele "tecido urbano camaleônico" (SENNETT, 2008, p.363). A cidade, ao mesmo tempo em que propicia o contato, provoca o acirramento das diferenças no mundo moderno, contribuindo para a segregação social e criação de estereótipos sociais. A massa multifacetada flagrada e ampliada pelas lentes das câmeras revela a mélange ${ }^{4}$ humana de que são formadas as cidades (PESAVENTO, 1996).

Os contrastes típicos dos grandes centros urbanos são facilmente detectados pelos olhares dos narradoresfotógrafos e servem como mote para reflexão a partir da "photomancia": os meios de transporte; variados tipos humanos em trânsito pela urbe; a mendicância; o mercado informal; o tráfico de drogas; a prostituição, enfim, componentes cada vez mais frequentes nas cidades que integram o painel urbano multifacetado.

\section{Referências}

AUGÉ, Marc. Não-lugares: introdução a uma antropologia da supermodernidade. Campinas: Papirus, 1994.

BAUMAN, Zygmunt. Modernidade líquida. Rio de Janeiro: Jorge Zahar, 2001.

BAUMAN, Zygmunt. Vidas desperdiçadas, Rio de Janeiro, Jorge Zahar, 2005.

BERMAN, Marshall. Tudo o que é sólido desmancha no ar. São Paulo: Companhia das Letras, 1986.

BOLLE, Willi. Fisiognomia da metrópole moderna. São Paulo: EDUSP, 2000.

DELLE DONNE, Marcela. Teorias sobre a cidade. Lisboa: Edições 70, 1990.

ECO, Umberto. Sobre os espelhos e outros ensaios. Tradução Beatriz Borges. Rio de Janeiro: Nova Fronteira, 1989.

FOUCAULT, Michel. Vigiar e punir: nascimento da prisão. Tradução Raquel Ramalhete. Petrópolis: Vozes,1987.

GINZBURG, Carlo. Mitos, emblemas e sinais: morfologia e história. Tradução Federico Carotti. São Paulo: Companhia das Letras, 1989.

GOMES, Renato Cordeiro. Todas as cidades, a cidade: literatura e experiência urbana. Rio de Janeiro: Rocco, 2008.

MACHADO DE ASSIS, Joaquim Maria. Obra completa. Rio de Janeiro, Nova Aguilar, 2008. v. 1-4.

PESAVENTO, Sandra Jatahy, O imaginário da cidade: visões literárias do urbano - Paris, Rio de Janeiro, Porto Alegre. Porto Alegre: Editora da Universidade/UFRGS, 2002.

SENNETT, Richard. Carne e pedra: o corpo e a cidade na civilização ocidental. Rio de Janeiro: BestBolso, 2008.

TEZZA, Cristóvão. O fotógrafo. 2. ed. Rio de Janeiro: Record, 2011.

Recebido: 31/05/2018

Aprovado: 03/11/2018

(D) SHEIla KATIANE STAUDT < heilastaudt@hotmail.com> Professora, IFRS Campus Canoas.

4 Expressão de Sandra Jatahy Pesavento em seu livro O espetáculo da rua. 